\title{
NATURAL LAW THEORY IN ITALY
}

\section{Teoría del Derecho Natural en Italia}

Teoria del diritto naturale in Italia

Francesco Viola ${ }^{1}$

Para citar este artículo:

Viola, F. (2020). "Natural Law Theory in Italy". Prudentia Iuris, N.

Aniversario, pp. 97-115.

DOI: https://doi.org/10.46553/prudentia.aniversario.2020.pp.97-115

\begin{abstract}
Natural Law Theories are influenced by particular cultural trends and philosophical traditions. The Italian trend is characterized, on the one hand, by the existence of a normative ethics grounded on human reason and inspired by the Christian faith according to Aquinas' doctrine, and, on the other hand, by a philosophy of history concerning processes of civilization according to Giambattista Vico's thought. These two cultural roots have developed in parallel and often in opposition, so Italian Natural Law Theories have been attracted now by rationalism, then by historicism without arriving at a point of balance. In the age of constitutionalism, the relevance of inner principles of positive law appears to allow their fruitful convergence.
\end{abstract}

Keywords: Natural Law Theory; Italy; Legal Philosophy; Law and Morality.

Resumen: Las teorías del Derecho Natural están influenciadas por tendencias culturales particulares y tradiciones filosóficas. La tendencia italiana

1 Abogado. Profesor Emérito de la Universidad de Palermo, Palermo, Italia. A cargo de la Cátedra de Filosofía del Derecho. Autor de numerosas publicaciones en la materia. Presidió (2010-2014) la Asociación Italiana de Filosofía del Derecho. Correo electrónico: francesco. viola@unipa.it. 
se caracteriza, por un lado, por la existencia de una ética normativa basada en la razón humana e inspirada en la fe cristiana, según la doctrina de Aquino y, por otro lado, en una filosofía de la historia sobre los procesos de civilización, según el pensamiento de Giambattista Vico. Estas dos raíces culturales se han desarrollado en paralelo y a menudo en oposición, por lo que las teorías italianas de Derecho Natural se han visto atraídas ahora por el racionalismo y luego por el historicismo sin llegar a un punto de equilibrio. En la era del constitucionalismo, la relevancia de los principios internos del Derecho Positivo parece permitir su fructífera convergencia.

Palabras clave: Teoría del Derecho Natural; Italia; Filosofía del Derecho; Ley y moralidad.

Sommario: Le teorie del diritto naturale sono influenzate dagli orientamenti culturali e dalle tradizioni filosofiche particolari. Il trend italiano è caratterizzato, da una parte, dalla presenza di un'etica normativa fondata sulla ragione umana e ispirata dalla fede cristiana, secondo la dottrina di Tommaso d'Aquino, e, dall'altra, da una filosofia della storia legata ai processi d'incivilimento secondo il pensiero di Giambattista Vico. Queste due radici culturali si sono sviluppate parallelamente e spesso in contrasto tra loro, sicché il giusnaturalismo in Italia è stato attratto ora dal razionalismo ora dallo storicismo senza raggiungere un punto di equilibrio. Nell'epoca del costituzionalismo l'attenzione per i principi interni alla positività del diritto ora sembra permettere una convergenza fruttuosa fra queste due tradizioni italiane del pensiero giuridico.

Parole chiave: Giusnaturalismo; Italia; Filosofia del Diritto; Diritto e Morale.

To explore the history of natural law theory in 20th-century Italy (see Fassò 1964a, 109-128; Pérez Luño 1971; Marini 1987; Lorenzi 1990) there is no need to make reference to political unification of the country in the second half of the 19th century. We can refer to a much older tradition of thought that rather marks the persistence of a cultural approach, despite chequered political and social vicissitudes. The fact is that the cultural unification of Italy came long before its political unification. Since every culture can be considered as an interpretation of human nature, it is legitimate to wonder whether there is a propensity of Italian culture towards a specific doctrine of natural law.

I will limit this exploration especially to the period that goes from the years after World War II, down to our own day, and I will entirely neglect 
studies on the history of natural law, even though they have had major importance in Italy. Does a natural law doctrine exist that is dominant in Italy in the second half of the 20th century?

I will say straightaway that the answer to this question will be a negative one. Rather than of a unitary doctrine it will be necessary to talk of some typical approaches to the problems of natural law that are persistent in Italian culture and derive from its tradition of thought.

\section{The italian tradition}

In this tradition the common fabric of society is represented by Catholic ethics, whose principles and values, until a few decades after World War II, were amply shared, though not always adequately practiced. For the Italian people, the Catholic ethic was identified for a long time with ethics tout court and it had no rival alternatives of any importance.

On this common basis there developed two orientations of thought that can emblematically be seen as going back respectively to St. Thomas Aquinas (1225-1274) and Giambattista Vico (1668-1744), both Neapolitan philosophers. The former represented both the theological origin of this normative ethic and its possible rational foundation, natural law being at once divine law and law of reason. Vico -to whom we owe a philosophy of history attentive to the way in which natural inclinations and the principles of reason are developing in the minds of men and in the work of civilization- represented the demand for a bond with praxis and with the concrete experience of social life and politics. Hence reason and history, divine will and human culture are the elements always present in the background to this tradition of thought.

One of the unquestionable characteristics of Italian reflection on natural law is given by the fact that these two orientations of thought, not incompatible per se, rarely fertilized one another but developed along parallel and often antagonistic lines.

The Italian interpreters of Aquinas have given life to varying interpretations oscillating between voluntarism and rationalism, but often rejecting attention to the historicity of human experience.

The followers of the Viconian line of thought, which actually did not produce a true legal- philosophical school and for long periods fell into oblivion, were concerned above all with the interpretation of political and civil history, abandoning Vico's undoubted religious inspiration and his attention to law.

If now, leaping forward a few centuries, we look, even superficially, at the 19th century, we have to recognize that the philosophical bases were 
not adequately developed in the sphere of Catholic thought, which had the monopoly on natural law theory ${ }^{2}$. Everyone recognizes a large dose of eclecticism in Christian thought itself and, more broadly, in all Italian philosophical culture down to our own day ${ }^{3}$. In the first half of the 19th century the only detailed discussions of natural law had an avowedly rationalistic imprint.

The glorious tradition of Christian thought had been seriously damaged by the impact with the Enlightenment, but it was not entirely dead. In the second half of the 19th century some scholars interested in legal and political problems quite consciously returned to the conception of natural law of St. Thomas Aquinas. Among them for depth of thought there stands out Luigi Taparelli d'Azeglio (1793-1862), who worked out a complete and detailed doctrine of natural law that still today is of some importance (see Taparelli 1849). Among these scholars there was certainly a conservative orientation aiming to oppose the spread of liberal individualism. Nevertheless, there is, especially on the part of Taparelli d'Azeglio, en endeavour not to impose the principles of natural law from above, but to see them as in some measure immanent in the history of customs and social praxis.

Following Pope Leo XIII's encyclical Aeterni Patris (1879), Catholic thought again found its identity and reprised the tradition of natural law as a basis for a moderate and prudent recognition of human rights (see Menozzi 2012).

In Italy the neo-Thomist movement developed until after the Second World War and to it we obviously also owe a determined conception of natural law. The orientations of this School were to have a lot of weight, for good and for bad, on the image of natural law that spread in Italian culture before and after the World War II.

In Italy neo-Thomism was a movement of thought linked to the Catholic Church much more than in other European countries. We have to remember that in Italy there were no state theology faculties, and still there are none. Catholic culture, even more after the political vicissitudes linked to the unification of Italy, was steeped in an ecclesiastical and clerical di-

2 One of the few exceptions is the philosophical system of Antonio Rosmini (17971855), a Catholic priest that succeeded in creating a dialogue between the Christian philosophical tradition and modern thought. For this purpose, he valorized Kant's thought against sensism and empiricism. However, he was isolated and looked on with suspicion within the Catholic Church itself.

3 A typical example of eclecticism in the legal-philosophical field is the thought of Gian Domenico Romagnosi (1761-1835), who blends naturalism and ethical finalism. It is not clear whether he is to be considered a supporter of natural law theory or of legal positivism. Nevertheless, he is a major scholar on theory of society and constitutional law. 
mension. Consequently, the neo-Thomist conceptions of natural law experienced a double separation: from lay culture, and from legal culture. They were set apart as theological-philosophical and ethical problems, while the prevailing orientation of jurists continued to be linked to legal positivism in legal science ${ }^{4}$, though anchored to Catholicism in private morality. Accordingly the Thomist doctrine of natural law remained in a defensive position towards lay culture and was not able to develop a capacity for dialogue and valorization of the universality of reason.

If we then look at the way of thinking of natural law, it mainly centred on the affirmation of absolute and unchangeable norms independent of historical variations and founded on the rational will of God or on human nature steeped in finalism in virtue of the principle of creation. A certain ramification was possible on the basis of the Thomist distinction of the derivation of natural law ad modum conclusionis or ad modum determinationis. Nevertheless, recourse to historical experience was not seen as necessary for knowing the principles of natural law, but rather for being aware of the variety of their applications (see Olgiati 1944).

The very concept of law was identified with justice seen as a supreme synthesis between internal action, linked to virtues, and intersubjective and social rules (see Olgiati 1932). The reduction to ethics leads to a loss of the autonomy of the concept of law. The neo-Thomists had to defend themselves from this accusation, and some, in order to face it, tried to separate more deeply external action from internal ones (see Graneris 1949).

From the accusation of lack of historicity, neo-Thomist thought was defended by invoking the distinction between ancient and Christian natural law, on the one side, and modern natural law on the other. The latter was held to be responsible for an abstract and unhistorical conception of natural law, while the former, in the wake of Aristotle, was held never to lose sight of the concreteness of moral experience. However, the true reason for the rejection of modern natural law theory lies in its links with rationalism and deism.

On the lay side ${ }^{5}$, historicism and idealism, which were the dominant philosophy of the time and denied the normative character of human nature, had in turn appropriated the thought of Vico to themselves, the other great interpreter of the Italian spirit, bending him to the needs of an immanentist philosophy of history. Benedetto Croce in 1910 and Giovanni Gentile

4 Dominant in the world of Italian jurists in the first half of the century is the institutionalism of Santi Romano, which is a rigorous legal positivist.

5 Among the few exponents of secular Catholic culture we can mention Eugenio Di Carlo (1882-1969) of the University of Palermo for his willingness to take into consideration the historical dimension of natural law (see Di Carlo 1966). 
in 1915, with their interpretation of Vico's thought, profoundly conditioned the approach to the Neapolitan philosopher but not so much to link him to Hegelian philosophy, rather because of the excessive importance given to the themes of aesthetics and poetics in comparison to legal ones, considered to have a low theoretical profile. Accordingly, historicism was no less abstract in its intellectual positions and the clash between Catholic and lay thought was played out on the plane of the greatest theoretical systems. In these cases, the fierce battle on principles was almost always accompanied by pragmatism not very attentive to values on the practical plane.

One also has to consider the situation of particular difficulty in which legal philosophy found itself. On one side, in order to be recognized as true philosophical speculation, it had to be closely connected to the dominant currents of thought, that is to say, at that time, to positivism, neo-Kantianism, and neo-idealism; on the other side, however, no adequate valorization of the legal phenomenon came from these philosophical orientations. Philosophical positivism considered law as an antiquated instrument of social control; neo-Kantianism tended to think of it in an outlook of mere appearance and coerciveness; neo-idealism now reduced it to economy (see Croce 1909) and now drowned it in ethics (see Gentile 1916). Accordingly legal philosophers almost always appeared to be heterodox in relation to the tradition of thought to which they too made reference and were therefore looked on with suspicion by pure philosophers. If the philosophers reduced them to mere jurists, the latter did not consider them as belonging to their guild.

The neo-Thomist orientation, or Catholic spiritualism in general, in actual fact represented the only doctrine of natural law in Italy before World War II. Certainly some demands of the problems of natural law were also accepted by the adversaries of natural law, and particularly those regarding the formation of more just positive law. Philosophical positivism spoke of "social idealities". One can also identify non-Catholic natural law orientations linked to a line of thought that starts from Filomusi Guelfi (18461903) and Igino Petrone (1870-1913) and is linked to the Neapolitan neoHegelian School (Augusto Vera and Bertrando Spaventa). But these were positions that were very close to historicism.

The only real doctrine of natural law originally different from the neoThomist one can be found in the neo-Kantianism of the Bolognese Giorgio Del Vecchio (1878-1970), the founder in 1921 of the Rivista Internazionale di Filosofia del Diritto (International Journal of Legal Philosophy), which circulated widely abroad too. The difference does not consist in the contents of natural law, which are still those of Christian ethics, but in the distinction between legality and justice. Del Vecchio maintains that the logical concept of law is independent of that of justice. Legality is a logical form that makes 
it possible to give legal meaning to social phenomena of intersubjectivity and is neutral from the evaluative point of view. But law moves towards the ideal of justice, which is its principle in terms of contents. The originality and importance of the thought of Del Vecchio, to whom we also owe later valuable writings on natural law (see, e.g., Del Vecchio 1954), is mainly in the working out of a definition of law that overrides the controversy between legal positivism and natural law theory, in that it is only on this basis that it is possible for this controversy not to be a dialogue of the deaf.

On the plane of ethical-political commitment, none of the forms of natural law present in Italy before the war was fully aware of the incompatibility between fascist ideology and natural law, developing an organic and combative critical opposition. This is proof of the abstract character of Catholic natural law in that period and its incapacity to tackle history.

\section{The natural law of jurists}

One of the most important cultural effects of World War II on legalphilosophical problems -as is well known- was renewed attention, not infrequently opportunistic, to natural law. This happened in general in the culture of the defeated countries, that is to say Italy and Germany ${ }^{6}$. There has been much discussion of the responsibilities of legal positivism regarding Nazi and fascist totalitarianism ${ }^{7}$. It is understandable that the whole configuration of pre-war culture was challenged without any distinction being made. Actually the true responsibility should have been sought not so much in legal positivism, but in the separation between ethical and legal culture. The upholders of legal positivism and natural law theory were equally responsible for this.

One of the first results of the rebirth of natural law was renewed attention to it on the part of jurists. Once more the initiative and the impulse came from the Catholic Church. Pope Pius XII had great sensitivity to law and advocated a new international legal order. His appeals were fully accepted by the Union of Italian Catholic Jurists (U.G.C.I. 1951). The central problem was the legal ethics of the jurist and his virtues. The work of the ju-

6 It is curious to observe the rapid conversion of idealist philosophers to natural law theory. From the school of Croce himself there was to come a defender of natural law (see Antoni 1959).

7 Uberto Scarpelli and Norberto Bobbio vigorously defended legal positivism against this accusation: the former on the basis of the connection between legal positivism and the constitutional and democratic state, the latter on the basis of the distinction between legal positivism as a theory and as an ideology. 
rist was undoubtedly linked to positive law and the value of legal certainty, but now it could no longer be affirmed that the drama of unfair law should or could remain only a private matter of conscience, especially when it took on very large proportions.

The variety of opinions present in this debate was the unmistakable sign of a development in the problems of the validity of natural law. First of all people once again proposed the neo-Scholastic position whereby natural law had at once a transcendent and a systematic character. Accordingly, where the jurist ascertained the contradiction between the positive norm and the natural one, he or she would have to recognize that the former is not true law (see Barbero 1953, 40). But this strong version ${ }^{8}$ of natural law theory received very little support and its own upholders did everything possible to reduce its negative impact on the value of certainty and on the duties of the role of the jurist. The weak versions insisted either on the difference between the single positive norm and the system of norms as a whole, or on the particular character of the norms of natural law. These were two moderate approaches that allowed a dialogue between positive law and natural law without implying a duplication of legal normative systems.

According to the first perspective there was a substantial difference between the legal system as a whole and the single norm. The former could never clash with natural law, since it was the objective order of social coexistence, an arrangement consolidated through the tests of history and therefore endowed with immanent rationality of its own. In this sense natural law is the sum of the constitutive requirements of positive law itself, whether derived from the structure of action or expressed in the internal values constituting a legal order. This was substantially the position of Giuseppe Capograssi (1889-1956), a legal philosopher who had a great influence on the training of Italian jurists in the post-war period. Capograssi, the upholder of a philosophy of legal experience, expressly harked back to Vico and spoke of the "natural law of the wise men", that is to say of the result of the work of reason displayed in history, underlining the deep needs of humanity (see Capograssi 1959). In this framework unjust law has to be somehow taken back, through interpretation, to the interior values of the positive order and thus purified of its contradictions.

We can consider this trend as being a fully natural law theory, although its upholders did not always accept this definition, which in the cultural imagination seemed to be an exclusive monopoly of the strong version. In its

8 A version is strong if it contains the following assumptions: Non-positive law exists; this law is valid by itself, that is to say without any need of human recognition; this law, being axiologically superior to positive law, prevails over it as regards compulsoriness (see D’Agostino 1993, 71). 
turn the philosophy of legal experience was engaged in opposing the historicist drift, which threatened it from inside. This task was faced differently by the disciples of Enrico Opocher of the University of Padua (1914-2004): through recourse to classical dialectics and ancient rhetoric (see Cavalla $2005)^{9}$, in the study of the potentialities inside the legal order (c.f. Gentile 2000), in investigations of the history of natural law theory (see Todescan 1973), and in legal theory inspired by German hermeneutics (see Zaccaria 1984a, 1984b).

The second trend rejected identification of natural law with a system of precepts. It consisted, instead, in a few fundamental or core precepts and in a set of orientations guiding the production of positive law. Today we would say that natural law is manifested above all through principles, that is to say general orientations for action. Consequently the irresolvable conflict between natural and positive law would come down to a few extreme cases concerning precepts, while it would only have a moral and not strictly legal value in the case of principles.

The innovations thus consisted in a differentiation of the ways of seeing the validity of natural law and in jurists' involvement in these problems, reserved in the past for legal philosophers and moralists. The latter aspect is strengthened by the presence of a legislative text steeped in ethicalpolitical values like the Italian Constitution that came into force in 1948. Since the constitutional text incorporated some principles that belonged to the natural law tradition, the fidelity to law typical of the jurist could be merged in some way with natural law theory. In any case it is significant that people began to speak of the "philosophy of jurists" (see Caiani 1955), which before the war would have seemed like nonsense. This philosophy does not abandon the unhistorical formalism typical of the Italian jurist (see Merryman 1966), but recognizes that values are incorporated in legal and institutional formulas, are "law in force" and therefore must be kept in mind in the procedures of legal interpretation and legal science.

The result of this evolution was a strengthening of the convergence on the constitutional contents of law, which for upholders of natural law theory were founded on the natural law in force, while for upholders of legal positivism they were positive law to all intents and purposes. But agreement always has the effect of paralyzing research. At that time in Italy there was no debate on the contents of fundamental legal values, but only on their classification as natural or positive law ones. A natural law doctrine should instead present itself as a programme of research on the precepts and principles of law, that is to say it should exert practical reasoning to trace and

\section{See Opocher 1984.}


justify legal rules. Moreover, this is by no means extraneous to the tradition of Italian legal science, which harks back to Roman law, to medieval jurisprudence and to ius commune, and which -as was well highlighted by Giuliani (1997)- could now use the resources of the new rhetoric and the theory of reasoning. But jurists in the age of codification had abandoned this tradition, unlike Anglo-Saxon jurisprudence. In conclusion, it can be affirmed that the two weak versions of natural law still need to be further extended and developed.

\section{Natural law theory as a theory of morality}

Hence one should not be surprised if the most vital focus of the debate moved onto the epistemological plane. As it was no longer the contents of precepts that classified a doctrine as natural law, then the stress was to fall on a determined foundation or on a determined justification. Norberto Bobbio perceived this problem with his usual lucidity when he long ago considered natural law theory not as a determined morality, but as a determined theory of ethics (see Bobbio 1965, 180). This was an objectivistic theory of ethics that presumed to base value contents on the cognitive plane. The conflict between natural law theory and legal positivism thus became a conflict between cognitivism and non-cognitivism of value judgments (c.f. Viola 1993). This epistemological controversy drew the main attention to itself, causing issues of normative ethics to fall into oblivion.

The division now concerned meta-ethics, the conception of science and legal interpretation, and the concept of law, that is to say whether it is fact or value. There developed a strong current of legal positivism with an analytical inspiration, which was inspired by the works of Hans Kelsen, Alf Ross, and H. L. A. Hart and became the main adversary of the natural law theory of ethics, using the Is- Ought question as its favorite weapon (see Bobbio 1965, 172; see also Carcaterra 1969).

Meanwhile, in more general Catholic philosophical culture neoThomism faded away and almost disappeared, without being replaced by a different and more adequate interpretation of the thought of Aquinas. It is true that Catholic culture in Italy in the post-war period was greatly influenced by the thought of Jacques Maritain, but especially with reference to political and social philosophy rather than to legal philosophy ${ }^{10}$. In actual

10 Maritain's most interesting work for legal philosophers was published posthumously in Italian even before being published in the original language, but unfortunately did not arouse sufficient attention (see Maritain 1985). 
fact natural law theory had run off into a thousand rivulets, no longer having a strong and unitary speculative basis. Obviously its eternal and invincible argument was kept alive, that is to say that it is necessary to admit a criterion of moral measurement of positive law if one wants to avoid the triumph of factuality. But the uncertainty remained about the way of founding this recta ratio on the cognitive plane and on its strictly "legal" character.

The essential connection between Christianity and natural law theory was sharply challenged by Guido Fassò (1915-1974), a legal philosopher of law at the University of Bologna and -as already stated- the author of the only complete history of legal thought still existing today. Fassò, in whom we again hear the voice of Viconian philosophy, clearly separates the plane of the absolute transcendence of moral and religious values from the institutional and social plane, which is necessary to cohabitation and coexistence and therefore has to accept a certain relativism and historicism of values, with their consequent inevitable secularization (see Fassò 1969; see also Ambrosetti 1985). The law is set on the latter plane, just as all social or rational moralities are in reality legal forms of coexistence in some contrast with the essential ultramundane spirit of Christianity. In this there is a good dose of mistrust in human reason, which to some extent is reminiscent of non-cognitivism (see Pattaro 1982) and the mysticism of Wittgenstein, but Fassò clearly rejects voluntarism. In this religious background for the construction of legal and political institutions he recognizes the educational importance of natural law seen as law of reason (see Fassò 1964b). This is empirical and historical Viconian reason that is not at all eternal and unchangeable, but essential for the guaranteeing of rights and freedom, that is to say for founding the values of constitutionalism. On this plane it is also possible to intercept the natural law theory of Thomas Aquinas, seen by Fassò as an upholder of critical and non-dogmatic reasonableness able to adapt to the historicity of human relations.

Despite the non-absolute value of natural law, this recognition of the importance of practical reasonableness and the use of Thomism along these lines is interesting. Fassò himself makes reference to the English legal tradition, which has developed law from the concrete demands of society interpreted by reason, a law that is not voluntaristic, as continental law is; it is positive natural law, to use Roscoe Pound's expression.

It must be remembered that some years before, an Italian with a Thomist background and a deep knowledge of English legal and political thought, Alessandro Passerin d'Entrèves (1902-1985), had maintained that the importance of natural law consisted more in its historical function than in its doctrine (see Passerin d'Entrèves 1954). And this historical function was precisely what was emphasised by Fassò, that is to say limiting the power of the state and protecting the individual against the sovereign's will. 
Crediting natural law with this "historical" merit, Bobbio noticed that for this reason an objectivistic theory of ethics was not necessary, in that the same merit must be attributed to other doctrines or philosophies that had nothing to do with it (see Bobbio 1965, 190). But natural law theory is not the only possible cognitive meta-ethic and it is doubtful whether constitutionalism and human rights are defended better on the theoretical plane by cognitivism or ethical relativism. In conclusion, for the fate of natural law theory the crucial point is not the content of natural law but its foundation, that is to say the concept of human nature. It would be senseless to go on speaking of "natural" law if this did not somehow mean an appeal to nature, and nevertheless the naturalistic fallacy would seem to prevent it.

To get over this difficulty it is necessary to offer a non-naturalistic interpretation of human nature and this required a new speculative effort. It was to this theoretical undertaking that Sergio Cotta (1920-2007) devoted his studies; he brought together an original Augustinian inspiration and an ontological revisiting of Husserl's phenomenology (see Cotta 1991). Cotta does not dwell on defending determined contents of natural law, in which he admits a good deal of historicity. The philosophical concept of "nature" cannot be reduced to mere factuality, but indicates the constitutive structure of an existential entity. The entity to which law refers is man. Philosophical investigation shows the structural characteristics of this entity and reveals its coexistential relationality. From this anthropological truth there derive objective duties, that is to say ones valid for every human being. Hence natural law is positive law that is justified by its corresponding to the structure of the entity to which refers. It is not ideal law, or naturalistic law, but law which is valid for being an expression of the human being. The principal task of natural law theory becomes justifying the compulsoriness of positive law, which substantially means answering the radical question "why law?" (see Cotta 1981). In this way Cotta manages to trace in positive legal systems some inalienable principles of a structural character, violation of which would make the coexistential relationship impossible (like the duty to respect the innocent and not to subjugate other's will). Such principles are not merely formal, because they express a sort of ontological a priori requisite, and not merely logical, and at the same time they need to be worked out in historical praxis. Limiting natural law exclusively to the first principle of practical reason, that is "good is to be done and pursued, and evil is to be avoided," would mean abandoning the contents of natural law to the becoming of history and to relativistic historicism.

Hence it is necessary -according to Cotta- to translate the old metaphysical ontology of Thomism into phenomenological and anthropological ontology. 
Cotta's thought to some extent harks back to the theme of the concept of law dear to Del Vecchio, whom he succeeded at the University of Rome. However, Cotta does not reduce the concept of law to mere logical formalism but rather shows that the form of legality implies some anthropological and ontological conditions.

This debate on natural law is set on the plane already specified by Bobbio, that is to say on the epistemological one. Cotta, indeed, agrees that the criterion of historical contents and that of social function are not adequate to define natural law theory. It is not the unity of a school or a doctrine, but the unity of a research model characterized by the question on the foundation of the law when it is sought in the nature of man (see Cotta 1989).

Sergio Cotta's teaching gave rise to a flourishing school of disciples, who, starting from a common original inspiration, moved in various directions, at times conflicting ones: the phenomenological orientation in a Heideggerian sense was chosen by Romano (1984), that of philosophical anthropology by D'Agostino (1984), and that of criticism of social functionalism by Montanari (1989).

Lastly, it must be mentioned that a possible resource for natural law conceptions came from logical studies on the ontology of the norm that were developed in Italy in a very sophisticated way by Conte (1989-1995).

This return of natural law problems to the philosophical dimension, in both an ontological and an epistemological sense, though of great speculative value, did not always satisfy the demands of jurists more interested in the contents of law that in its foundation. Besides, jurists favorable to natural law had been satisfied with constitutional values and therefore went back to entrenching themselves in legislative formalism in defense of the certainty of law. By contrast, it was to be jurists animated by leftwing ideologies that attempted alternative interpretations of positive law in the name of a search for more just law (see Barcellona 1973). In any case legal philosophy of law once again estranged itself from the attention of jurists (c.f. Viola 1994).

\section{The return of normative ethics to within Positive Law}

From the 1970's a cultural phenomenon of great importance for the search for natural law began to be apparent. We have said that the only undisputed firm point was agreement about the contents of Christian ethics. But in Italian society at that time this convergence gradually vanished. The introduction of divorce (1970) and the legalization of abortion (1978) did away with common ethics and led to pluralistic fragmentation of moral 
convictions. Since public deliberation requires reasonable accord at least on some central themes, attention began once again to be paid to issues of normative ethics that meta-ethical researches had caused to be neglected.

Debates on just law imply the existence of and therefore the search for objective criteria, and this confers plausibility on the natural law outlook. But the principles and precepts of natural law need to be defended on the argumentative plane from within legal experience. On the other hand -as already mentioned-purely philosophical reflection on law does not capture the attention of jurists oscillating between formalism and ideologism. Nevertheless, the crisis in common ethics shifted to positive law the task of guaranteeing the shared values necessary for all civil cohabitation (see Viola 1989). Paradoxically this is a situation favorable to natural law, which has always had to respond to two contradictory accusations, i.e., being ethics and not law, and being based on nature as a fact. But now the general concept of "nature" had become the crucial issue of law and morality (see Lombardi Vallauri 1990).

Today in Italy -as in the rest of the world- the legislation is forced to deal with issues that are ethically important not only on the public plane but also in the private sphere. Accordingly, themes like bioethics, ecology, the future generations, feminism, and gender become significant chapters of legal philosophy. In relation to the answers provided by normative ethics, two conflicting groups are configured, which in a sense reflect the traditional division between laymen and Catholics. Nevertheless, it would be wrong to identify this opposition with that between legal positivism and natural law theory, both because "lay people" too often defend an objective ethic, and because the "Catholics" do not always base their ideas on the normative concept of human nature. Among the numerous contributions to this ongoing debate we can consider the writings of Francesco D'Agostino, who, on the basis of rational justification, rigorously defends the contents of the Christian tradition of natural law (see, for example, D'Agostino 1998). In any case history itself takes on itself the task of refuting the ferocious aggression by Piovani against natural law theory considered as anti-modern (see Piovani 1961, 11).

Natural law theory today does not present itself as a theory of morality, but as an ethic deriving either from the normative character of nature or from a specific use of practical reasonableness. For this purpose, it is necessary to regain not only normativity, but also all the breadth of the concept of "nature". Natural law theory -as Luigi Lombardi Vallauri observed-is not concerned only with the nature of man, but also with the nature of things and with the very nature of law. Natural law does not only concern norms of conduct, but also norms of organization (see Lombardi Vallauri 1987). The same procedures, to which today attempts are made to reduce all posi- 
tive law, are not merely arbitrary, but have to respect certain constraints of value and practicability. Constitutionalism, democracy and human rights have binding internal rules; they have -as Fuller would say- their own internal morality. The "naturalness" of positive law lies in everything that is taken away from the full disposition of human will. In this sense there is a sort of minimal natural law theory that is at the basis of our present-day legal culture. It is based on refusal to reduce values to facts, on rejection of absolute subjectivism (see Lombardi Vallauri 1981) and on the defense of the individual against public power (see Cattaneo 1994).

On the contents of structural or procedural natural law today in Italy there is a high degree of consensus, only recently impaired by the debate on the revision of the Italian constitution. The most difficult problem concerns natural law of conduct, because it remains linked to the controversial concept of the nature of man, around which the division remains between Catholic and secular thought. For this problem to be solved it is necessary to overcome two obstacles still present in Italian natural law.

The first obstacle is conciliation between the universal form of the precept of natural law and its content, which to some extent is historical (see Sala 1971). It is once again a question of succeeding in fruitfully harmonizing Thomas Aquinas and Giambattista Vico, that is to say reason and culture, principles and history.

The second obstacle lies in the difficulty of developing practical reasoning without being conditioned by ideological presuppositions. Only greater trust in reason and in its practical use (see Viola 1990) can favor communication and dialogue between conflicting orientations. Philosophers have to achieve better knowledge of the argumentative processes of jurists and the latter have to be able to perceive the non-positivistic presuppositions of their arguments and interpretations.

Some signs that look to the future are favorable to a renewed approach to the problems of natural law seen as a search for the first principles of legal reasoning.

Neo-Thomist thought and the influence of Jacques Maritain having been worn out, the line of thought inspired by Thomas Aquinas is struggling to find new lifeblood in Italy (c.f. also Azzoni 2008). The Italian translation of the main work of John Finnis (i.e., Finnis 1996) does not seem to have made a major contribution to renewing Italian natural law theory, which is not very sensitive to analytical philosophy. Greater hopes lie in the internal evolution of contemporary positive law and the theory deriving from it.

In this connection the most significant turn consists -in my opinion-in the slow but gradual abandonment of the identification of law with rules. We tend to think of natural law in the same way as we think of positive law. 
But in positive law today the importance of other normative elements is recognized, over and above the rules established by the authority.

Dworkin's distinction between rules and principles has been widely discussed in Italy. Positive law today appears more like a set of interpretative processes than a pre-established system of norms and the problem of the sources of law is revived. The primacy of interpretation shifts the focus from above to below, from normative validity to the use of legal rules. And then we wonder whether this praxis has some internal primary goods or guiding principles, what, if any, they are, and what type of normativity they exhibit. Further, the study of human rights (see Viola 2000) favors reconsideration of the theory of natural law, and forces jurists themselves to abandon all rigorous formalism and challenge the rigid separation between validity and justice, law and morality (see U.G.C.I 1993).

Nevertheless, although it is now clear that the concept of nature cannot be reduced to mere factualness but has to refer to the unity of meaning of the fundamental ontological spheres of human experience, it is still too far from and external to social praxis and historical processes, which constitute the real life of law. A pathway still not much explored is that which seeks in historical experience the constants of legal rules, having recourse to the acquisitions of cultural anthropology (see Scillitani 1996), or to trans-cultural laws (see Carcaterra 1992; Cosi 1993), or to the suggestions of Maritain and Gadamer on the "dynamic schemes" of action, or, finally, to the "reflective judgment" of Kant (see Mathieu 1989). One can endeavor to arrive at natural law along a plurality of research pathways.

\section{References}

Ambrosetti, G. (1985). Diritto Naturale Cristiano (Christian Natural Law). Milan. Giuffrè.

Antoni, C. (1959). La Restaurazione del Diritto di Natura (The Restoration of Natural Law). Venice. Neri Pozza.

Azzoni, G. (2008). "Lex Aeterna e Lex Naturalis: Attualità di Una Distinzione Concettuale (Lex Aeterna and Lex Naturalis: Modernity of a Conceptual Distinction)". In La Vitalità del Diritto Naturale (The Dynamism of Natural Law). Ed. F. Di Blasi e P. Heritier. Palermo. Phronesis, 159-210.

Barbero, D. (1953). Studi Di Teoria Generale del Diritto (Studies of General Theory of Law). Milan. Giuffrè.

Barcellona, P. (ed. 1973). L'uso Alternativo del Diritto (The Alternative Use of Law). Bari. Laterza.

Bobbio, N. (1965). Giusnaturalismo e Positivismo Giuridico (Natural Law and Legal Positivism). Milan. Edizioni di Comunità. 
Caiani, L. (1955). La Filosofia dei Giuristi Italiani (The Philosophy of Italian Lawyers). Padua. Cedam.

Capograssi, G. (1959). Opere (Works). Milan. Giuffrè.

Carcaterra, G. (1969). Il Problema della Fallacia Naturalistica (The Problem of Naturalistic Fallacy). Milan. Giuffrè.

Carcaterra, G. (1992). Lezioni di Filosofia del Diritto. Norme Giuridiche e Valori Etici (Lectures on Legal Philosophy. Legal Norms and Ethical Values). Rome. Bulzoni.

Cattaneo, M. A. (1994). Persona e Stato di Diritto (Person and Rule of Law). Turin. Giappichelli.

Cavalla, F. (2005). Retorica, Processo, Verità (Rhetoric, Trial, Truth). Padua. Cedam.

Conte, A. G. (1989-1995). Filosofia del Linguaggio Normativo (Philosophy of Normative Language). Turin. Giappichelli.

Cosi, G. (1993). Il Logos del Diritto (The Logos of Law). Turin. Giappichelli.

Cotta, S. (1981). Giustificazione e Obbligatorietà delle Norme (Justification and Normativity of Norms). Milan. Giuffrè.

Cotta, S. (1989). Diritto Persona Mondo Umano (Law Person Human World). Turin. Giappichelli.

Cotta, S. (1991). Il Diritto Nell'esistenza. Linee di Ontofenomenologia Giuridica (Law in Human Existence. Elements of Legal Ontophenomenology). Milan. Giuffrè.

Croce, B. (1909). Filosofia della Pratica: Economica ed Etica (Practical Philosophy: Economics and Ethics). Bari. Laterza.

D’Agostino, F. (1984). Diritto e Corporeità (Law and Bodyness). Milan. Jaca Book.

D’Agostino, F. (1993). Filosofia del Diritto (Philosophy of Law). Turin. Giappichelli.

D’Agostino, F. (1998). Bioetica (Bioethics). Turin. Giappichelli.

Del Vecchio, G. (1954). "Mutabilità ed Eternità del Diritto" (Mutability and Eternity of Law). Jus, Rivista di Scienze Giuridiche 5: 1-14.

Di Carlo, E. (1966). "Diritto Naturale e Storia" (Natural Law and History). Circolo Giuridico L. Sampolo 37: 9-42.

Fassò, G. (1964a). Il Diritto Naturale (The Natural Law). Turin. Eri.

Fassò, G. (1964b). La Legge della Ragione (The Law of Reason). Bologna. Il Mulino.

Fassò, G. (1969). Cristianesimo e Società (Christianity and Society). Milan. Giuffrè.

Finnis, J. (1996). Legge Naturale e Diritti Naturali (Natural Law and Natural Rights). Ed. F. Viola. Turin. Giappichelli.

Gentile, F. (2000). Ordinamento Giuridico tra Virtualità e Realtà (The Legal Order between Virtuality and Reality). Padua. Cedam.

Gentile, G. (1916). I fondamenti della Filosofia del Diritto (The Grounds of Legal Philosophy). Pisa. F. Mariotti.

Giuliani, A. (1997). Giustizia ed Ordine Economico (Justice and Economic Order). Milan. Giuffrè.

Graneris, G. (1949). Contributi Tomistici alla Filosofia del Diritto (Tomistic Contributions to Legal Philosophy). Turin. Sei.

Lombardi Vallauri, L. (1981). Corso di Filosofia del Diritto (Course of Legal Philosophy). Padua. Cedam.

Lombardi Vallauri, L. (1987). "Diritto Naturale" (Natural Law). Jus, Rivista di Scienze Giuridiche 34(3): 241-61. 
Lombardi Vallauri, L. (ed. 1990). Il Meritevole di Tutela (Who is Deserving Protection). Milan. Giuffré.

Lorenzi, G. (1990). "Il Dibattito sul Diritto Naturale in Italia dal 1945 al 1960" (The Debate on Natural Law in Italy from 1945 to 1960). Verifiche 19(3): 327-70; 19(4): 489-533.

Marini, G. (1987). "Il Giusnaturalismo nella Cultura Filosofica Italiana del Novecento" (Natural Law Theories in the Italian Philosophical Culture of the $20^{\text {th }}$ Century). In Storicità Del Diritto e Dignità Dell'uomo. Naples. Morano, 281-320.

Maritain, J. (1985). Nove Lezioni Sulla Legge Naturale (Nine Lectures on Natural Law). Ed. F. Viola. Milan. Jaca Book.

Mathieu, V. (1989). Luci ed Ombre del Giusnaturalismo (Lights and Shadows of Natural Law Theories). Turin. Giappichelli.

Menozzi, D. (2012). Chiesa e Diritti Umani. Legge Naturale e Modernità Politica dalla Rivoluzione Francese ai Nostri Giorni (Church and Human Rights. Natural Law and Modern Politics from the French Revolution to Nowadays). Bologna. Il Mulino.

Merryman, J. H. (1966). "Lo Stile Italiano: La Dottrina” (The Italian Style: The Doctrine). Rivista Trimestrale di Diritto e Procedura Civile 20(4): 1170-216.

Montanari, B. (1989). Fenomeni Sociali e Lettura Giuridica (Social Phenomena and Legal Reading). Turin. Giappichelli.

Olgiati, F. (1932). La Riduzione del Concetto Filosofico di Diritto al Concetto di Giustizia (The Reduction of the Philosophical Concept of Law to the Concept of Justice). Milan. Giuffrè.

Olgiati, F. (1944). Il Concetto di Giuridicità in San Tommaso d'Aquino (The Concept of Legality in St. Thomas Aquinas). Milan. Vita e Pensiero.

Opocher, E. (1983). Lezioni di Filosofia del Diritto (Lectures on Philosophy of Law). Padua. Cedam.

Passerin d'Entrèves, A. (1954). La Dottrina del Diritto Naturale (The Doctrine of Natural Law). Trans. V. Frosini. Milan. Edizioni di Comunità.

Pattaro, E. (1982). "Sull'Assoluto. Contributo allo Studio del Pensiero di Guido Fassò" (On the Absolute. Contribution to the Study of Guido Fassò's Thought). Rivista Internazionale di Filosofia del Diritto 59: 42-94.

Pérez Luño, A. E. (1971). Iusnaturalismo y positivismo jurídico en la Italia moderna (Natural law Theories and Legal Positivism in Modern Italy). Bologna. Real Colegio de España en Bolonia.

Piovani, P. (1961). Giusnaturalismo e Etica Moderna (Natural Law Theories and Modern Ethics). Bari. Laterza.

Romano, B. (1984). Il Riconoscimento come Relazione Giuridica Fondamentale (Recognition as Legal Fundamental Relationship). Rome. Bulzoni.

Sala, G. B. (1971). "Lex Naturae e Storia" (Lex Naturae and History). Rivista di Filosofia Neo-Scolastica 63(3): 241-94.

Scillitani, L. (1996). Studi di Antropologia Giuridica (Studies on Legal Anthropology). Naples. Jovene. 
Taparelli d'Azeglio, L. (1849). Saggio Teoretico del Diritto Naturale Appoggiato sul Fatto (1840-1843) (Theoretical Essay of Natural Law Grounded on Fact). Rome. Civiltà cattolica.

Todescan, F. (1973). Lex, Natura, Beatitudo: Il Problema della Legge nella Scolastica Spagnola del Sec. XVI (Lex, Natura, Beatitudo: The Problem of Law in the Spanish Scolastic of the $16^{\text {th }}$ Century). Padua. Cedam.

U.G.C.I. (1951). Diritto Naturale Vigente (Natural Law in Force). Rome. Studium.

U.G.C.I. (1993). Diritto Naturale e Diritti dell'Uomo all'Alba del XXI Secolo (Natural Law and Human Rights at the Beginning of the $21^{\text {st }}$ Century). Milan. Giuffrè.

Viola, F. (1989). Diritti dell'Uomo, Diritto Naturale, Etica Contemporanea (Human Rights, Natural Law, Contemporary Ethics). Turin. Giappichelli.

Viola, F. (1990). Il Diritto come Pratica Sociale (Law as Social Practice). Milan. Jaca Book.

Viola, F. (1993). "Ragion Pratica e Diritto Naturale: Una Difesa Analitica del Giusnaturalismo" (Practical Reason and Natural Law: an Analytical Defense). Ragion Pratica 1(1): 61-81.

Viola, F. (1994). "Nuovi Percorsi dell'Identità del Giurista" (New Paths of Lawyer's Identity). In Filosofia del Diritto: Identità Scientifica e Didattica Oggi. Ed. B. Montanari. Milan. Giuffrè, 119-31.

Viola, F. (2000). Etica e Metaetica dei Diritti Umani (Ethics and Meta-Ethics of Human Rights). Turin. Giappichelli.

Zaccaria, G. (1984a). Ermeneutica e Giurisprudenza. Saggio sulla Metodologia di Josef Esser (Hermeneutics and Jurisprudence. Essay on Josef Esser's Methodology). Milan. Giuffrè.

Zaccaria, G. (1984b). Ermeneutica e Giurisprudenza. I Fondamenti Filosofici nella Teoria di H. G. Gadamer (Hermeneutics and Jurisprudence. Philosophical Foundations in H. G. Gadamer's Theory). Milan. Giuffrè. 